\title{
MAGMA-SEDIMENTS INTERACTION IN THE ÁGUAS EMENDADAS KAMAFUGITIC DIATREMES, GOIÁS ALKALINE PROVINCE, BRAZIL.
}

Tereza Cristina Junqueira-Brod $_{1}^{1,2}$, José Affonso Brod ${ }^{1,2}$, José Carlos Gaspar ${ }^{1,2}$ and Elisa Soares Rocha Barbosa ${ }^{1,2}$ ${ }^{1}$ Universidade de Brasília, Brazil, ${ }^{2}$ CNPq, Brazil

\section{INTRODUCTION}

The Late-Cretaceous Goiás Alkaline Province (GAP) is located in central Brazil, 400 kilometres southwest of Brasília, in the northwest border of the Paraná Basin. It is one of the largest kamafugitic provinces in the world (Junqueira-Brod et al. 2002). Three domains can be recognised, on the basis of the occurrence mode of the alkaline rocks. Plutonic complexes dominate from the Iporá region to the North, whereas subvolcanic rocks, including diatremes, crop out mostly in the central part of the province, in the Águas Emendadas region, and extensive lava flows with associated dykes and plugs occupy the southern portion, in the Santo Antônio da Barra region (Figure 1).

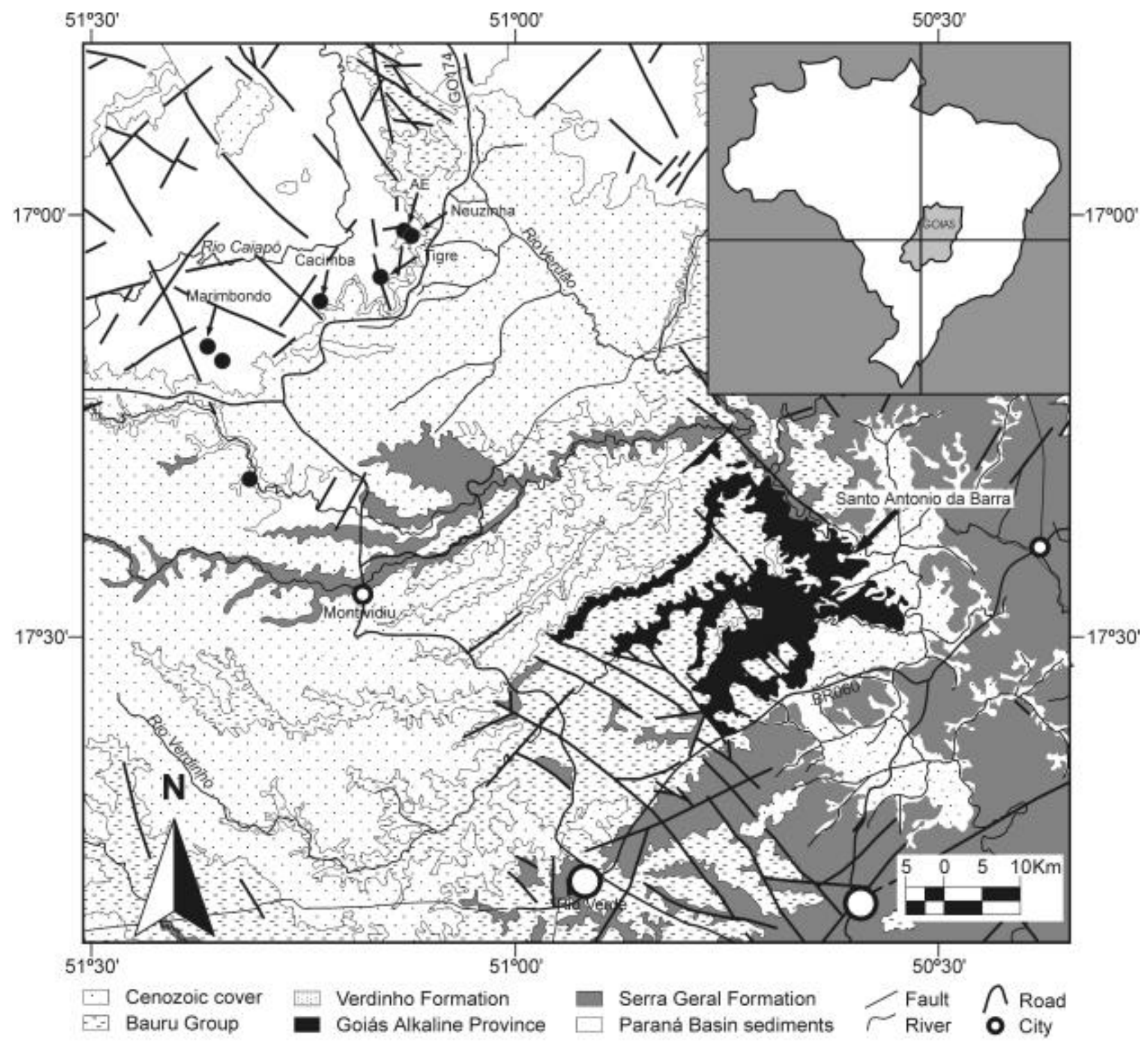

Figure 1 - Geological map of Águas Emendadas and Santo Antônio da Barra Regions showing the main occurrences of cretaceous alkaline rocks, modified from Lacerda Filho et al. (2000). 
A number of features indicating magma-sediment interaction occur in association with the diatremes in the central GAP and with lava flows in the South. The description and discussion of such features are the scope of this work.

\section{GEOLOGICAL SETTING}

The Alkaline-Carbonatite Santo Antônio da Barra Subprovince (Gaspar and Danni, 1981), located in the southernmost part of GAP (Figure 1), comprises volcanic rocks of kamafugitic affinity (Sgarbi et al. 1998) emplaced as lava flows, alternated with rare pyroclastic deposits, overlying the Early-Cretaceous Parana Basalts. Late dykes and plugs include fourchite, melamonchiquite, phonolite and trachyte (Gaspar and Danni, 1981). K-Ar dating (Hasui et al., 1971) yielded an $85 \mathrm{Ma}$ age for the volcanic rocks, and JunqueiraBrod et al. (2002) calculated the volume of the Santo Antônio da Barra lavas as $23 \mathrm{~km}^{3}$. Toward the top of the volcanic sequence, epiclastic rocks of the Verdinho Formation, comprising mainly by volcanic sandstones and conglomerates, with subordinate pelites, are intercalated in the kamafugitic lava flows.

In the Águas Emendadas Region, located between the towns of Amorinópolis and Montividiu (Figure 1), kamafugitic diatremes, dykes, plugs, and pyroclastic deposits are emplaced in Devonian sandstones of the Aquidauana Formation and covered by the sandstones of the Late-Cretaceous Bauru Group. The main petrographic types were earlier described as olivine melanephelinites, olivine-analcite melanephelinites, olivine analcimites, nephelinites, micro-ijolites, basanites and tephrites (Danni et al. 1990), but Junqueira-Brod (1998) and Junqueira-Brod et al. (2000), established the kamafugitic affinity of these rocks on the basis of whole-rock chemistry, petrographic and mineral chemistry evidence, reinterpreting the former nephelinites as kamafugites and the analcimites as melaleucitites.

The central GAP diatremes share the same field setting, whereby a central kamafugitic breccia body intrudes the Aquidauana sandstone, is cut by irregularly shaped dykes and conduits, and covered by kamafugitic, melaleucititc and rare basanitic lava flows (Figure 2).

\section{MAGMA-SEDIMENT INTERACTION}

By the time of diatreme emplacement the Paraná Basin sediments of the Aquidauana Formation were most probably well lithified. Away from the intrusions the unaltered sandstone has a reddish colour, is slightly friable, and very homogeneous, showing a poorly defined centimetre-scale planar bedding. Near the contact with the diatremes, however, various contact effects and magma-sediment relationships may develop, depending mainly on local variations in sediment porosity and/or magma volatile content. Three main types of contact relationships are recognised: contact metamorphism, development of columnar jointing on the sediments, and various degrees of mixture between sediment and fragmented magma.

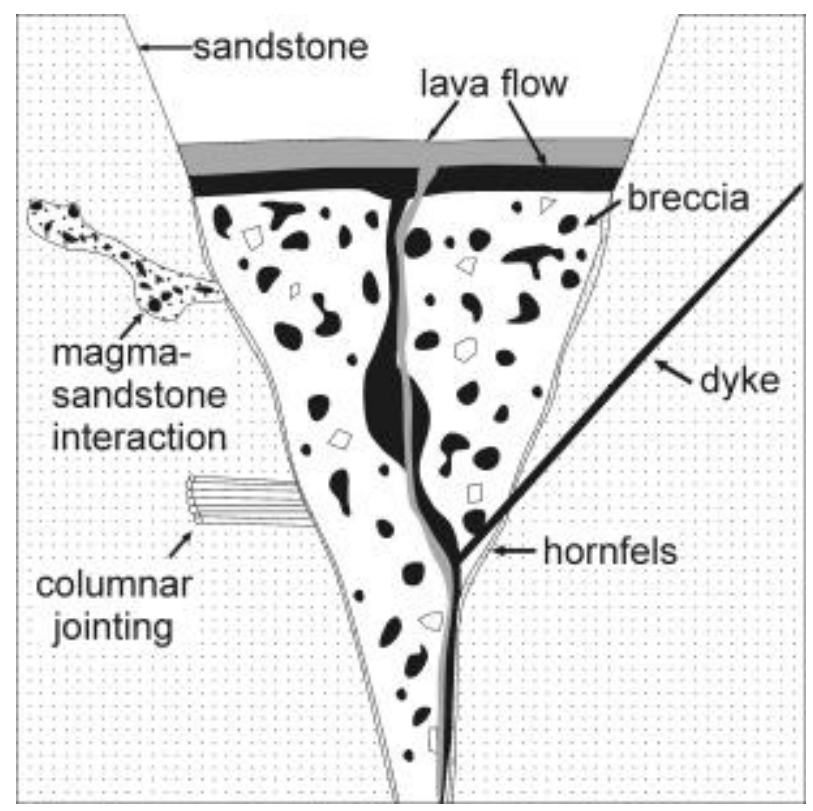

Figure 2 - Schematic model of field relations in diatremes of the Águas Emendadas region.

The products of contact metamorphism vary from a homogeneous hornfels to a mottled rock showing irregular brown patches. Occasionally, sub-centimetric spheres of siliceous vitric material are formed. Quartz is strongly recrystallised, almost completely erasing the original sandy fabric. The contact zones have a fairly regular width, varying from 2 to 30 centimetres. This type of contact effect was recognised in all studied diatremes.

The development of columnar jointing in the sandstones was only observed in the contact zone of the Águas Emendadas Diatreme. The columns have a cross section of about 4 centimetres, are horizontally oriented, up to 1 metre long, and have a very regular spatial distribution. Compared to the homogenous hornfelses, columnar-jointed sandstones are less intensely recrystallised and show lighter, almost white shades of colour. 
Mixture between magma and sandstone often occurs in the GAP kamafugitic diatremes. When preserved in situ, it is always represented by the injection of breccia material from the diatreme into the Aquidauana Formation wall rock. The hybrid bodies generated in this way vary in shape from lobes to tabular, with no preferred orientation (Figure 3). The resulting rocks are composed of rounded quartz grains mixed with juvenile kamafugitc material, plus cognate fragments and xenoliths.
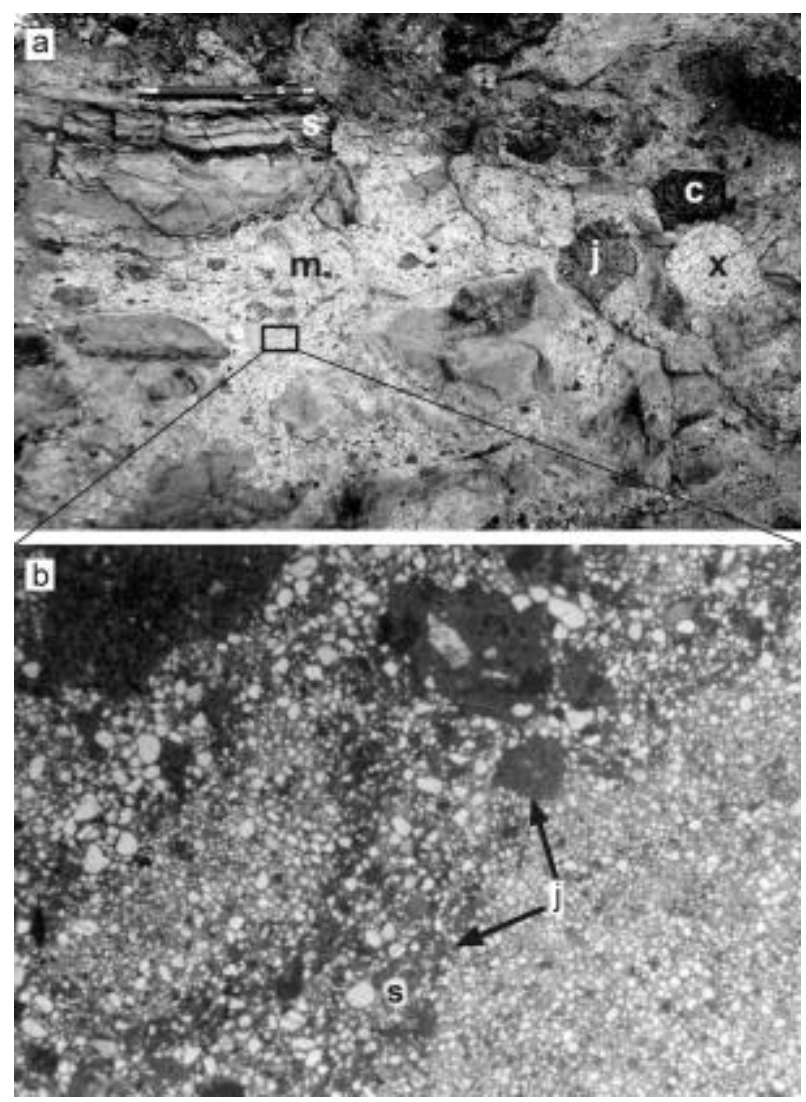

Figure 3 - a) Magma-sandstone interaction lobe inside the Aquidauana Formation in the border zone of Neuzinha Diatreme, central GAP; b) Microscopic detail of the matrix showing loose quartz grains pervaded by magmatic material. Field of view $0.8 \times 1.2 \mathrm{~cm}$. Plane-polarized light. Symbols: $\mathrm{m}=$ mixture matrix; $\mathrm{s}=$ sedimentary material; $\mathrm{j}=\mathrm{juvenile}$ material; $c=$ cognate fragment; $x=x e n o l i t h$.

In these mixture domains, fragments of the sandstone wall are displaced and rotated, show variable degrees of thermal alteration, acquire a mottled aspect given by fader patches, and are thermally affected by the magma injection. The original planar bedding is usually lost. Locally, pieces of the kamafugitic breccia, and/or loose fragments detached from it, are immersed in a matrix that resembles the original sandstone and consists of quartz grains cemented by devitrified kamafugitic glass.
The forced entry of magma helps disintegrating the sandstone fabric, as shown in Figure 3.

Fragments of the above described magma-sediment mixtures are rarely found within the breccia matrix (Figure 4), and only very near the diatreme borders. This indicates that such fragments were picked up shortly after being formed, still during the emplacement of the diatreme and, therefore, had not enough time to mix and homogenise into the breccia body. Their colour is darker than the lobes found within the country rock, due to their higher content of the magmatic component. Large poikilitic phlogopite phenocrysts often mark the contact of the mixture fragment with the breccia.

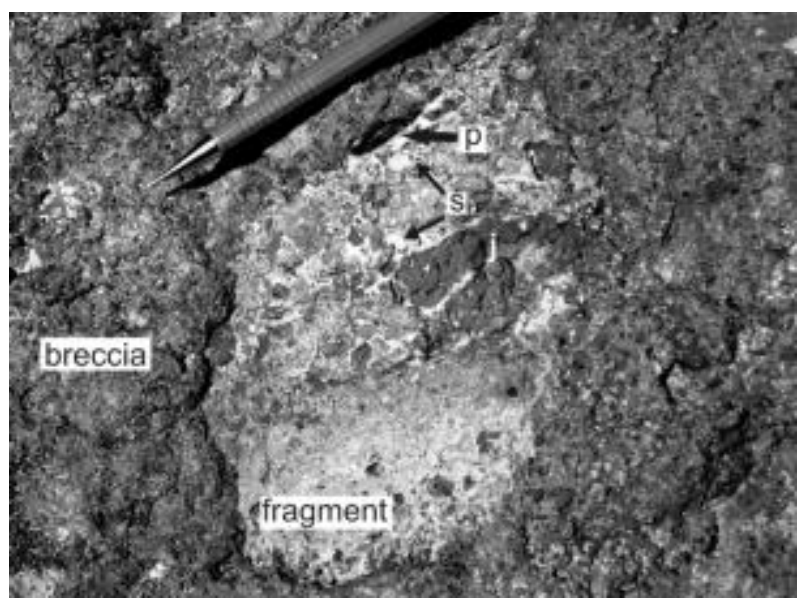

Figure 4 - Fragment of mixture of sedimentary material (s) and juvenile magma (j), note the development of large phlogopite (p) phenocryst in the fragment border

In Santo Antônio da Barra (southern GAP), lava flows are commonly emplaced over newly deposited epiclastic sediments, produced by the dismantling of previous eruptions. This may also result in magmasediment mixtures, formed by the interaction between the hot kamafugitic lava and the (probably wet) unconsolidated sediment. These mixtures represent true peperites in the sense of White et al. (2000) and Skilling et al. (2002)

The Santo Antônio da Barra peperites form smallvolume irregular bodies, occurring as centimetric discontinuous layers at the bottom of some flow units. They consist of irregular patches of mixed magma and sediments, where sediment-dominated areas are usually red to dark brown matrix and magma dominated areas are dark green. The peperite is composed by clay minerals and quartz, representing the sedimentary component, and olivine, pyroxene and glass, representing the magmatic material (Figure 5). 


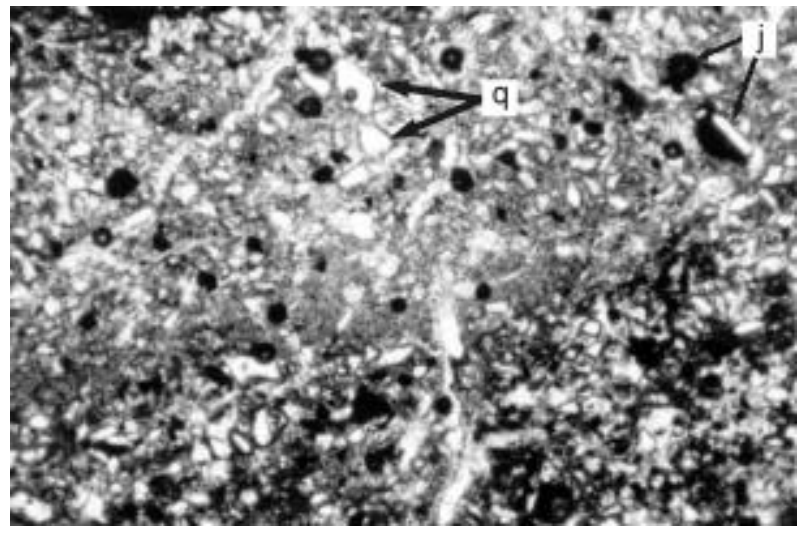

Figure 5 - Photomicrograph of the Santo Antônio da Barra peperite matrix, showing fine sediment and quartz grains (lighter domain) mingling with kamafugitic lava (dark domain). Field of view $1.3 \times 2 \mathrm{~mm}$. Plane-polarized light. Symbols: $q=q u a r t z ; j=j u v e n i l e$ fragment.

\section{DISCUSSION}

The usage of the name peperite has been recommended in the genetic sense, i.e. to designate deposits formed by disintegration and mingling of hot magma with contemporaneous, unconsolidated or poorly consolidated, typically wet sediments (White et al., 2000, Skilling et al., 2002). As such, the term is adequate to classify the magma-sediment mixtures of Santo Antônio da Barra, but would not strictly apply to the rocks described in the Águas Emendadas Region, since the latter were produced by injection of Cretaceous kamafugitic magmas into the Paleozoic sandstones. Despite the fact that the mixing materials are not coeval, all other features, both field and microscopic, conform to the descriptions of peperite elsewhere. It is, therefore, likely that the mechanical processes involved in the genesis of peperite-like rocks in diatremes from the Águas Emendadas region were similar to those leading to peperite genesis.

The occurrence of irregular lobes extending from the diatremes into the country sandstone implies that pressure within the conduit exceeded confining pressure, at the time of emplacement. Therefore, it is possible that a juvenile gas front penetrated weaker zones in the wall rock, enhancing the primary sandstone porosity and leading to disruption of the original fabric. As a result, some portions of the previously lithified sandstone were converted into a set of loose quartz grains and sandstone fragments, much like an unconsolidated sediment.

In case any pore water was present, this would provide a further means of disaggregating the sandstone, as the water vapour pressure raised in response to the temperature increase during the emplacement of the diatremes. There is no evidence that water actually entered any of the diatreme bodies, although the presence of late-stage large phenocrysts of phlogopite indicates that magma reacted with country-rock pore water in the external lobes.

Ultimately, the pressure gradient, coupled with high country-rock porosity would have lead to the mechanical failure of the sandstone, and the mingling of the rapidly cooling, outward moving magma with individualised quartz sandgrains. Once some weak or void spaces were created, the highly fluidised breccia material was allowed to enter the disintegrated sandstone and interact with it, forming a peperite breccia.

Regardless of strict nomenclature requirements, neither peperite-like mixtures (e.g. in diatremes of the Águas Emendadas region, central GAP) nor peperite stricto sensu (e.g. associated with the Santo Antônio da Barra kamafugitic flows, southern GAP) have been previously reported from this province, although they appear to be relatively common.

\section{ACKNOWLEDGEMENTS}

The authors wish to thank CNPq - Brazilian Council for Research and Development, for a Ph.D. grant to TCJB, undergraduate grant to ESRB, and research grants to JCG and JAB. 


\section{REFERENCES}

Danni, J.C.M., Silva, A.J.G.C., Cerqueira, M.R., 1990. Petrography and geochemistry of the Cretaceous alkaline rocks of the Serra do Caipó, southwest Goiás. Proc. 36 Congresso Brasileiro de Geologia, São Paulo, Brazil, pp. 1872-1882. (in portuguese)

Gaspar, J.C., Danni, J.C.M., 1981. Petrographic and volcanological aspects of the Santo Antônio da Barra alkaline-carbonatite Province, soutwest Goiás. Revista Brasileira de Geociencias 11, 74-83. (in portuguese)

Hasui, Y., Cartner-Dyer, R.E., Iwanuch, W., 1971. Geochronology of the alkaline rocks of Santo Antônio da Barra, GO, Proc. 25 Congresso Brasileiro de Geologia, São Paulo, 1971, pp. 253-258. (in portuguese)

Junqueira-Brod, T.C., 1998. Cretaceous Alkaline Igneous Rocks from the Águas Emendadas Region, Goiás, Central Brazil. MSc Thesis, Univ. of Durham, UK.

Junqueira-Brod, T.C., Brod, J.A., Gibson, S.A., Thompson, R.N., 2000. Mineral chemistry of kamafugites and related rocks from Águas Emendadas region, Goiás state. Revista Brasileira de Geociências 30, 403-407.

Junqueira-Brod, T.C., Roig, H.L., Gaspar, J.C., Brod, J.A., Meneses, P.R., 2002. The Goiás Alkaline Province and the extent of its kamafugitic volcanism. Revista Brasileira de Geociências 32, in press. (in portuguese)

Lacerda Filho, J.V., Rezende, A., Silva, A., 2000. Brazilian Geological Mapping Programme. Geology and Mineral Resources of the Goiás State and Federal District. 1:500000 map and text. CPRM / METAGO / UnB, Brasília, Brazil. (in portuguese)

Sgarbi, P.B.A., Clayton, R.N., Toshiko, K.M., Gaspar, J.C., 1998. Oxygen isotope thermometry of Brazilian potassic volcanic rocks of kamafugitic affinities. Chem. Geol. 146, 115-126.

Skilling, I.P., White, J.D.L. \& McPhie, J., 2002. Peperite: a review of magma-sediment mingling. Jour. Volcanol. Geoth. Res 114, 1-17.

White, J.D.L., McPhie, J. \& Skilling, I., 2000. Peperite: a useful genetic term. Bull. Volcanol. 62, 65-66.

Contact: T. C. Junqueira-Brod. Universidade de Brasília, Instituto de Geociências. Brasília, Brazil. 70.910-900. E-mail tcjbrod@unb.br 